Mark Dimunation

\title{
Red Wine and White Carpets: What We Didn't Learn in Library School, or When the Dog and Pony Goes Bad
}

(A short musing on the education of a rare book curator in a newly revised professional edition without an overarching metaphor and free of all show tune references)

I WOULD LIKE TO OPEN WITH a bit of received wisdom that was actually passed on to me when I was a newly minted rare book librarian. The story goes like this: His first day at work, the curator of rare books finally manages a few quiet moments in his new office. Surveying the space, suitably impressed with the appropriate decor (sufficiently professional, but not stodgy), he opens the drawer of his massive desk. There he finds three sealed envelopes, left in the otherwise empty drawer by his predecessor. In sequence they are labeled "Open at the time of your first professional crisis," "Open at the time of your second professional crisis," and "Open at the time of your third professional crisis." He closes the drawer and thinks nothing of them until a few weeks later when he bungles a major deadline for an ongoing project. Fearing the worst, he hides in his office until he remembers the envelopes. He rips open the first and pulls out a card that reads simply: "Blame your predecessor." Being a young man of convenient scruples, he does so and survives without consequence. Several months have passed when the next firestorm erupts. "They will fire me if they find out," he thinks to himself as he fumbles for the second envelope. The message inside is again a simple one: "Reorganize." This he does as well, restructuring the entire division until the arrangement masks his recent failure. Several years into the job, now a bit cocky and coasting a little, he alienates a major donor and loses a significant gift as a result. With complete confidence he opens the third envelope. The message is simple and clear: "Prepare three envelopes."

I am not sure I would actually recommend three-strikes-and-you're-out as a strategy for the newcomers to the field. It certainly is not Library Management 101. In a less extreme manner, though, we have all had that experience of finding ourselves in completely vexing situations in our work, feeling at a loss and desperately flip- 
ping through our library school training in search of a solution that just does not seem to be there. Some solutions often come at the cost of hard knocks; others carry that peculiar feeling that we are reinventing the wheel. At a more general level, how many of us have stepped into a new position, uncertain of what it is we are supposed to do and of what we are responsible for at a higher level? Were we properly prepared?

To determine whether our professional schooling is serving us well, perhaps it would be useful to take the pulse of our profession as it now stands in relationship to curatorial positions of fifty years ago. If I were to look at the activities, responsibilities, and available technologies associated, say, with my work, and contrast those to the milieu of my predecessor's job, we would find that a very different set of competencies is in play.

Although the Library of Congress (LC) is more than 200 years old, the nation's rare book collection has functioned as a division only since 1944. I am the sixth designated curator of rare books in the library's history. My predecessors include V. Valta Parma, Arthur A. Houghton Jr., and Frederick R. Goff, who was promoted to chief in 1945. Goff served for nearly thirty years. His presence and his erudition are inescapable.

Goff was a book scholar and a consummate collector who had the great fortune to arrive in the halcyon days when curators spent the bulk of their day "curating," that is, building and studying collections. Those of us who are custodians of collections today face tasks, responsibilities, and technologies that would confound Dr. Goff. In fact, I suspect that other than the rare book symposia and the exhibition program at LC, Frederick Goff would not recognize his own job today. But I keep his accomplishments in the forefront to remind me and my colleagues that we went into this work because of the books. In the end, the real measure of our own work will be what we have done to further the knowledge and appreciation of the collections that we have the great privilege to build and administer.

The thread that connects the world of Frederick Goff to our own is perhaps best summarized by Dr. Goff himself. In a sweet essay, "The Delights of a Rare Book Librarian," delivered in 1974, two years into his retirement, Goff shared his thoughts about the spirit of our profession:

\footnotetext{
"Rare Book Librarians are a happy breed of men and women. We share common experiences and common pleasures, but there is nothing common about us. There is excitement in our lives for we work daily with the fabric of what has made the world what it is. We are an integral part of that world .... There are no saints
} 
among us that I know of, but we are blessed in many ways. As temporary custodians of the world's greatest books and manuscripts which record man's highest and also his lowest aspirations and his unending struggle to understand the world about him, to improve or to change it, or even unwittingly to destroy it, we share a personal destiny with the world of the past and the expectations and hope of the world to come. We are concerned. We have a sense of humor. We are aware that we have a special privilege to understand the motivations of a special mystique."

Prior to his promotion to chief, Goff negotiated what has been described recently as one of the greatest acts of cultural philanthropy of the twentieth century-the gift of the Lessing J. Rosenwald Collection on the History of the Illustrated Book. With the Rosenwald collection firmly guaranteed, Goff launched a rich and fruitful career, producing more than sixty publications - including detailed studies of the Dunlap Broadside, the Peter Force Collection, Caxtons in America, and the nature of fifteenth-century publications - and supported the publication of the landmark five-volume bibliographical reconstruction of Thomas Jefferson's library. All this, while at the same time acquiring the Alfred Whital Stern collection on Lincoln, the Giant Bible of Mainz, and the famed Bay Psalm Book of 1640. Of the more than 8,000 incunables in the collections, Frederick Goff acquired 5,600. And, of course, there is his signature work: the publication of his famous census of fifteenth-century books, Incunabula in American Libraries.

When Goff signed on to his position, the Rare Book Collection comprised 127,000 volumes. Today the collection numbers well more than 800,000 volumes. I live in a very different world than that of my predecessors. Our language is different, and that difference mirrors the pace and emphasis of our daily work. Goff's vocabulary included card sets, multiliths, cardex, microcard, order department, secretary, and carbon copy. Today, my language is as if from the moon: HVAC, EEO compliant, indirect cost recovery, vendor code, pixel count, Web harvesting, K-12, keywords, and bar codes.

This gibberish reflects more than a mere change in language or technology, more than simply a discovery of new means to achieve traditional efforts. We face our daily work from a new perspective. What has evolved over the past fifty years is in essence a new profession. To some degree our objectives remain related to the past. The fundamental nature of our profession, our "personal destiny" as Goff would have it, remains the same: to collect, protect, and interpret. But the context is entirely revamped. Within this new perspective many of us face the need to reposition our collections in terms of the larger institutional vision, and our relationships

1. Frederick Richmond Goff, The Delights of a Rare Book Librarian: Delivered on the Occasion of the Second Annual Bromsen Lecture, April 27, 1974 (Boston: Trustees of the Public Library of the City of Boston, 1975). 
with constituents, once firmly and comfortably built around a model of shared interest in the materials and an understanding of altruism, have now shifted dramatically. We are called upon to create avenues of access for all levels of understanding and for individuals who are not even physically present to work with the materials. We are asked to transport physical objects, laden with meaning and history, and propel them through a virtual world.

\section{The Nature of our Education}

We have been asking whether our professional education has made this shift with us; whether our training, based in the fundamental concerns of our profession, has indeed prepared us to become professional special collection librarians. When I enrolled in library school back when God was a boy, I entered an MLS program. Two years later, I walked out of South Hall at Berkeley with an MLIS, armed with an extra letter on my degree and a portfolio of courses covering subject reference, cataloging (including the new AACR2), serials management, PL1 programming, descriptive bibliography, database management, the history of the book, and the Harvard series on problem management. Despite my clearly stated intention to become a special collections librarian, I was being trained as an all-purpose academic librarian. The rare book component of my education, as such, was largely the product of my own petulance: "If we let you do an independent study, will you stop interrupting the class with these questions?"

When the $I$ joined the $M, L$, and $S$ on my degree, formal training for special collections librarians was in the process of moving down the food chain. For those of us who lived through this specific transition, we have to acknowledge that much of what we do professionally is the product not of our formal education as librarians, but of our training in an unspoken apprenticeship — the informal, seat-of-the-pants, sink-or-swim experience that we gained as we moved from entry-level to junior to senior positions in our field.

The notion of apprenticeship, of course, is not a new concept for our colleagues who entered the field through archival doors. Archivists and manuscript librarians were inculcated into a more established understanding that theory was absorbed through repeated practice, that standards were best learned and established by the doing, and, perhaps most important, that description and arrangement grew out of a long tradition of concentrated interaction with the users. The recent flood of internships, fellowships, mentoring programs, and discussions of core competencies for special collections librarians is a signal that the profession has begun to recognize what the archival world has known for a long time- that this informal apprenticeship needs some formality and that the skill sets requisite for special collections librarianship are not necessarily those being supplied in library school. 
For my generation, which I am horrified to report predates the arrival of the personal computer, library school education was established on a baseline foundation, something akin to learning map skills or learning a language, so that we would later recognize the landmarks and possess the ability to speak with the natives when we started our professional journey. Here I do not mean to suggest that it was all a wash. I did indeed receive a firm foundation in librarianship, better perhaps than what the current crop of students seems to be receiving. I went out into the world with a strong notion of the theories and principles of librarianship. I did, for example, learn how to catalogue rare books (albeit at that time this included specific entry formats for typewritten catalog card sets- "for author main entries indent the title two spaces; subjects receive Arabic numerals"). My introduction to descriptive bibliography, MARC coding, and subject analysis remains with me to this day.

But as for the real stuff that occupies most of my professional time-collection development and management, preservation, donor development, outreach and interpretation - these were largely unaddressed in my formal training. I suspect that my colleagues who were fortunate enough to find a library school program with an actual rare book track were all the better for it.

Nevertheless, the reality of our work is that we occupy our time with practical application. Theory and overview might well guide our decisions, but it is in the doing that we gain skill and expertise. No amount of classroom discussion regarding the principles and guidelines of collection management, for example, can prepare us for the experience of walking into a vault of 800,000 rare books, and realizing that these are now placed in our care. That the collections need preservation surveys and sequenced conservation treatments, that it is prudent to conduct full inventories on a regular schedule, that the vaults should be arranged to accommodate use, size, and environmental considerations - this is all well understood in theory. But how we actually carry out these tasks, how we plan for them, implement them, and pay for them-these are skills that are not currently well taught in library school.

In essence, I suppose I am building a case for a vastly different format for the education of rare book librarians, one that has a more potent mixture of classroom theory and direct practicum. Difficult, certainly, and likely quite cumbersome to bring into operation, but the notion comes from the experience of recalling what we did not know when we moved into the field.

One reason that Rare Book School has been so successful is that it directly addresses the paucity of library school courses specific to special collections librarianship. 
It does so at the introductory level (for those who do not know what they do not know) and at the more experienced, focused level (pinpointed professional training for those of us who do know what we do not know).

So, were we prepared? Armed with our lecture notes, our case studies, and our field trips, we launched a career and ran smack into the wall that separates "knowing" from "doing." All that training, and when you get right down to it we actually had to deal with collections and people and facilities and administrators. In what I see as the four crucial areas of our work-custodianship, stewardship, advocacy, and outreach - most of us learned the hard way.

\section{Custodianship}

You cannot call yourself a professional until you have coped with a major leak in the stacks. Only after this primitive initiation ceremony of plastic sheeting, wet vacs, and industrial-strength floor fans can you say that your mettle has really been tested. It is difficult to recall at three o'clock in the morning if you actually had a lecture on disaster preparedness in library school. One envisions that in the future, library school students will be bussed out to a fire department training ground, one of those bleak empty landscapes with the lone cement tower, where they will practice schlepping mops and chucking baskets of wet books until they learn their lesson.

Certainly it is the nature of our work, and indeed of most professions, that the practical application of theory is learned on the job. This is in part what constitutes an entry-level position. But we are in the business of preserving culture. We face tasks, although assuredly mundane, that, if not done properly, can wreak havoc and literally destroy the past. We cannot afford to leave the fundamentally important custodial tasks of conducting inventories, managing stacks brimming with antiquarian materials, or designing processing procedures to a trial-by-fire experience. What they did not tell us in library school is that our major responsibility, after we know what we are doing, is to mentor the next generation of the profession.

\section{Stewardship}

Regardless of our specific position—reader services librarian, archival processor, digital collections specialist, rare book cataloger-whatever the task might be in front of us, we are all tied to the fundamental responsibility of stewardship: the development and interpretation of our collections. This, for me, is the heart of the matter. It is not something that can be taught, really; perhaps this is why we so often refer to "passion" when we discuss the requirements for our work. Our education certainly gives us the tools that can assist us in becoming able stewards: 
collection assessments, appraisals, approaches to collection development, and an understanding of the book market. But how we embrace and utilize them requires savvy and a basic connection to the materials and the stories they tell.

Here is where I believe the admonition that we are turning to the wrong model to educate special collections librarians stands true. Certainly the art of collection development and the assessment of programmatic need are based in experience. The more practical the experience, the better. What they did not tell me in school was that after I had made my assessments, I would have to make choices and set priorities, that I would not have the funds to cover my grand design. And that even worse, the more tangential and obscure the particular purchase might be in relationship to the core collection, the more likely it was that it was attached to a faculty member prone to histrionic flailing and operatic protests that the library was not supporting his path-breaking research. No one taught me how to politely tell a hyperventilating faculty member to go away.

There also is an aspect of stewardship that relies purely on chance-the right person in the right setting at the right moment. We have all had these moments. Mine always seem to be prefaced by a swift cold breeze of panic: "What do you mean you can't find it?" Distress turns into jubilation when the ensuing search uncovers not only the stray item, but a long-forgotten gem as well. And for every one of those phenomenal moments of coincidence, there are those moments of the pure bliss of discovery, what Dr. Goff called "a special mystique."

\section{Advocacy}

Just because they like our stuff does not mean they share our agenda. If we really believe that special collections are at the heart of the research library, we need to play on the entire field. We need to be defenders of the faith without the rigidity of righteousness. "Special" also can be lonely, and sometimes it means being the exception. To avoid this, many of us have learned that we need to understand, support, and participate in larger librarywide initiatives, policies, and procedures. Better to weigh in on librarywide policy committees and work with other units than to be set aside or, even worse, dismissed as problematic.

We have a responsibility to advocate for the profession. Of late, there have been efforts to bolster the field of librarianship by reaching out to recent PhDs. Ours is indeed a viable profession, one that in the world of academic and research institutions should have an equivalent sense of academic accomplishment. Indeed, many of us came into the field on a dual track and understand the value and the impetus behind these efforts. But we will do our profession an injustice if we allow our specific training in librarianship, rare books, and archives to be reduced to a few 
quick introductory sessions in order to fast-track post-docs into the field. I do not object to the idea of outreach; there is great merit in infusing our ranks with a wider range of experience and perspective. But if we, as special collections librarians, do not determine and broadcast those aspects of our work that distinguishes our profession, they will be defined for us. It is no coincidence that in the past year I have sat on three distinct national and international committees to define the core competencies of our profession for the twenty-first century.

However, I feel that our work in the area of core competencies has been a little underreported. So set aside "passion" and "savvy" and "pizzazz." Here is the actual product of our labors thus far. The core competencies for special collections librarians are: trustworthy, loyal, helpful, friendly, courteous, kind, obedient, cheerful, thrifty, brave, clean, and reverent ... Jackie Dooley spoke the truth in commenting on another presentation at the 2005 preconference: we have a lot of important work to do that should go well beyond listing attributes. We need to define the characteristics and guidelines of our field in a way that can be understood by administrators and educators.

By way of a warning, I recall a moment when I was giving a presentation to a freshman writing class at Cornell. They were emphasizing medieval texts. As I placed each manuscript and incunable on the table, I noticed a student at the other end straining to get close to the books. Of course, we immediately snagged him. By the end of the year he was working for us. He stayed for four years and was one of those brilliant student assistants who mastered printing, exhibition prep, archival description, and Web design. We had spawned a rare book librarian! We proudly sent him off to library school with his fresh copy of Gaskell and his own set of loupes. He blossomed and stayed on for his PhD. But you know how kids are: he never wrote, and we were unaware of the evil forces at play. When we finally saw him, his conversation was littered with fancy words such as informatics, constituent profiling, and systems analysis. With the degree completed, the call finally came-"I got a job!" With my eyes tearing up, finally knowing that the spirit of the guild had been handed on to the next generation, I asked, "Which one?" "I am doing complex project information flow for Boeing." If we do not distinguish our chosen profession, they will define it for us.

\section{Outreach}

As many have pointed out, we have, as a profession, witnessed a significant shift in expectations around our curatorial responsibility, which is to create new means of access and to interpret our collections. It is a dramatic shift, I believe. New approaches to librarywide outreach and inclusion of new constituencies bring with them the demand for new approaches. Many of these new avenues are spawned by 
the Web and digitization programs. These new capabilities, which I believe have the potential to position special collections at the heart of the research program, demand that we select from, and interpret our collections in, an entirely new fashion. Professor Margaret Mitchell of the University of Chicago, who gave a rousing talk at the 2005 RBMS Preconference on teaching with special collections, was quite right: Presentation is interpretation.

The what and how of it is daunting, to say the least. And although it is all well and good to encourage forays into the world of $\mathrm{K}-12$ and popular interest, how many of us are able to translate our training into the skills needed to produce educational packets for third-graders or classroom instruction manuals for schoolteachers? These curriculum development skills were not on the menu when I enrolled in library school. What was once peripheral to our vision as special collections librarians is now pushed into our range of focus-Web catalogues, interactivity, school manuals, three-dimensional representations. These are not of our field; rather, they are tools and are part of a larger, librarywide initiative. Do we need to understand them and use them? Absolutely. Do we actually need to do them ourselves? Not necessarily.

Better that we position ourselves as stakeholders for the content and perhaps let someone else do the work. Sometimes when you need something done, the best thing you can do is to lobby for and support another division's opportunity to take on the work. We would be wise to argue for perspective, proportion, and appropriateness and take caution that we respect the integrity of our materials before we replace their meaning with flash. Because of the Library of Congress's express mission, I likely produce more K-12-directed materials than most of my colleagues. But I have to confess that I sometimes worry that we are circling all our wagons around the wrong campfire. Sometimes outreach is simply a stretch.

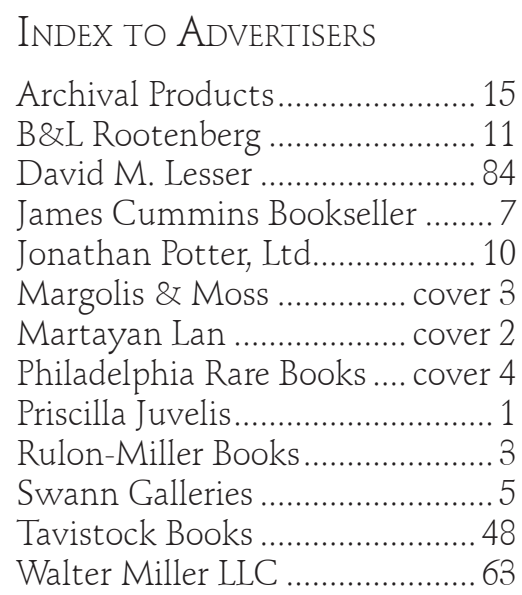

Fortunately, I was not asked to actually construct the link between education and experience in this paper, so I have no easy response to the questions presented elsewhere in this issue. But I can say this, and perhaps it is obvious: what the profession does at its preconference, as it has always done once a year, is part of the solution-seasoned professionals and newcomers gathering together to talk about our work, our challenges, and our solutions. 
When Congress acquired Thomas Jefferson's private book collection to restore the Library of Congress holdings after their destruction by the British in 1814, John Adams wrote to Jefferson admitting that "I envy you this immortality." There is a certain immortality that comes with our profession as well. Those of us who have been around for a while have begun to recognize that the names of our predecessors emerge in our professional vocabulary as nouns or verbs"Have you checked it in Goff," "Use the Hinman and compare the collation." So I thought that because we were never informed of this potential tribute in library school that I would speculate a bit as to the profession's future vocabulary:

- Schreyer-a significant classical or learned text bound in an elegant dress binding: "The collector trembled as he clutched his first purchase, a schreyerized copy of the Oresteia."

- Belanger-any grouping of a dozen identical bibliographic objects: "These are perfect for the History of the Book course," said the instructor as he unwrapped a belanger of Paine's famous pamphlet.

- Dooley—a handcart specifically designed for archival storage boxes: "Get those boxes on the dooley and take them out to the reading room."

- Smyth (archaic spelling) — technical term, adjective and verb, from letterpress printing. The act of adjusting the type bed to produce a perfect, classical page of printing: "Step aside, Mr. Baskerville," he said as he smythed the leading for the hundredth time.

- Holzenberg - ... [long, silent pause]

\section{What I Did Not Learn in Library School}

Finally, in order to spare the next generation of special collections librarians our own rugged path, I want to offer a few words of wisdom I picked up along the way. This is what I did not learn in library school:

- "Other duties as assigned" means vacuuming after receptions.

- Never call them "inkies" in public.

- Hypnerotomachia-pick a pronounciation and stick to it.

- Sometimes the phrase "Would you like this to be considered as a gift?" actually works.

- Resist efforts to reduce our entire world to the word analog. Develop an exquisite vocabulary and force others to use it.

- Letter opener or frosting spatula-make one of them your friend or develop a reasoned argument against slicing uncut books.

- Comparing moveable metal type to the typewriter key is no longer a viable didactic technique. 
- Wash your hands-it's good for you and better for the books.

- The opposite of always having too much to do is unemployment.

- Remember that when you are gone, the books will still be there-act accordingly.

- Go the distance.

- The trick to managing people is to think about them, not yourself.

- If you believe that no one ever reads exhibition labels anyway, they will.

- If you are wrong, freely admit to it.

- If a colleague is wrong, forgive and get over it.

- When staff complain that the vault is too cold, tell them to put on a sweater.

- Always bring an extra bulb for the projector.

- Always hire someone who actually understands PowerPoint.

- If you are in the habit of saying, "By the time I finish explaining what they need to do, I could have done it myself," you will always end up doing it yourself.

- Red rot knows when you are wearing your favorite suit.

- Unless you have an archival processor with absolutely nothing to do, never open a box.

- The simple fact that donors are giving you something that belongs to them is reason enough to treat them with respect, courtesy, and a thankyou note.

- Goff is off, Hain is a pain.

- Unless you are rushing off to a vaudeville performance immediately following your dog and pony, the only time you wear white gloves is when the Librarian of Congress is watching.

- Book dealers know a lot about very different things—learn from them.

- Sometimes book dealers are wrong.

- As sure as the sun will rise, if you offer an open microphone, Terry Belanger will ask a question.

- It is OK to translate Petrus Apianus into Peter Apian; it is not OK to call Johann Gutenberg "John."

- Every book has a story to tell. Listen to it, learn it, and embrace it-it will make you a very good curator and a much better human being.

And finally, when you find yourself standing at a podium in a large, all-too-familiar hotel conference room, enveloped in mirrors and chandeliers of dubious taste and facing an audience of your fellow travelers, pause and remember those who are no longer here and know that they are part of your history. Renew your promise to keep their work and their spirit alive. Scan the hall and recognize those in the room who were here before you-who taught you, who quietly suffered through your 
mistakes, who celebrated your accomplishments, and who pushed you forward on your path, only to counsel you again and again. Acknowledge those in the room who have followed you and take an oath to do the same for them. Find your peers who joined the parade with you side by side and relish your good work, your triumphs, your gray hair, those silly moments that only long-standing friends and colleagues can muster, and marvel at the fact that we have all made it here. Then remove your reading glasses, straighten up your notes, survey the room full of people that you have grown up with and have come to love and admire and say to yourself: "There is no such thing as 'just a librarian."”

\section{David M. Lesser Fine Antiquarian Books LLC}

One Bradley Road \#302, Woodbridge, CT 06525

Tel: (203) 389-8111 Fax: (203) 389-9113

Email:dmlesser@lesserbooks.com Website: http://www.lesserbooks.com 